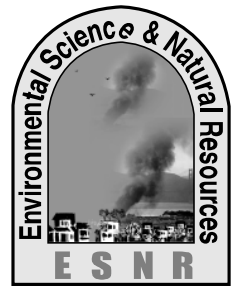

J. Environ. Sci. \& Natural Resources, 6(1): 167 - 171, 2013

ISSN 1999-7361

\title{
Integrated Approach to Wastewater Use in Agriculture: A Pilot Study in Rajshahi City Corporation Area
}

\author{
A. Chowdhury ${ }^{1}$, M. Z. Alam ${ }^{1}$ and A. A. Masum ${ }^{2}$ \\ Department of Civil Engineering, Rajshahi University of Engineering \& Technology, Rajshahi-6204, \\ Bangladesh
}

\begin{abstract}
Demand for water is increasing in the world parallel to increase in population and industrialization. In many developing countries, wastewater is the only source of water for irrigation during dry periods. Besides, wastewater is high in nutrient content which reduces the use of chemical fertilizers for crop cultivation. After a certain period, it will be unable to irrigate with ground water because of its limited quantities and contamination. To overcome this difficulties waste water may be a suitable source to meet the irrigation demand if properly managed and utilized in convenient way. In this study, wastewater samples were collected from four places of Rajshahi City Corporation (RCC) for determining water quality parameters. Analysis of these impurities were performed with strict quality control and quality assurance using the internationally accepted analytical chemical methods for the determination of their harmful effects on crops and found that most of the parameters exceed the permissible limits. The major problem in using wastewater in agriculture in the project area is the high level of faecal contamination. Thus, efforts are geared toward finding ways of utilizing the previously unused sources of water and/or recycling wastewater.
\end{abstract}

Keywords: Biological quality, Irrigation, Rajshahi City Corporation, Waste water

\section{Introduction}

Due to climate change the earth is warming as well as rainfall intensity is reduced and poorly distributed over the year in Rajshahi District. In drought season, ponds, lakes, river become dry and then waste water becomes main source of irrigation. Ground water table during dry season becomes lower and difficult for cost effective pumping. In some areas, salinity is a major problem that greatly hampered soil structure and crop yield. There is a possibility of arsenic contamination for deep pumping of groundwater which finally has a tendency to enter into the food chain by cultivating crop. In contest with surface and groundwater, waste water is available in dry season in Rajshahi City Corporation drain and competition among the farmers observed for using waste water. Wastewater contains beneficial crop nutrients e.g. nitrogen, phosphorus, potassium, zinc, copper as well as suspended organic materials, microorganisms, and in some cases, heavy metals. Wastewater contains many nutrients needed for plant growth including.

The objectives of the study are to measure waste water parameters which is harmful for agriculture at field level and compare their test values with the standard FAO and WHO guidelines; to evaluate the potential harmful effect of waste water contaminants on crops yield and to find out the process of reducing this harmful effect for optimum crop yield.

\section{Historical Background}

A study was carried out in Rajshahi City by the Wastewater Agriculture and Sanitation for Poverty Alleviation in Asia (also known as WASPA Asia project) on wastewater irrigation and agriculture practices, for the Comprehensive Assessment program of the International Water Management Institute (IWMI). The objective of the project was to improve the livelihoods of urban and peri-urban farmers who are using wastewater in agriculture; and the communities who are responsible for producing the wastewater or consuming the agricultural produces. To do this, a holistic approach and sustainable solutions are required along the whole chain of wastewater production, management and use; from improved sanitation to contaminant reduction, waste treatment, disposal, safe use in agriculture and promotion of hygiene behavior (Jayakody et al., 2007).The major sources of wastewater in RCC are presented in figure 1.

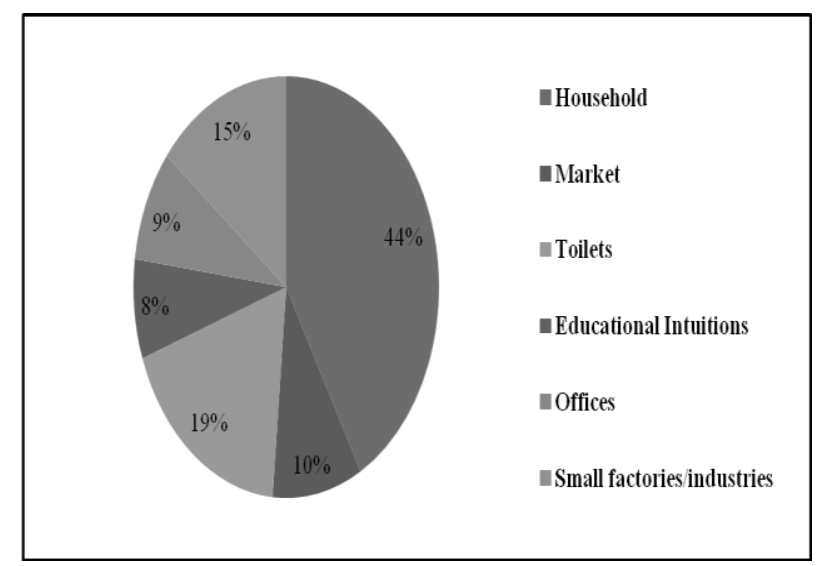

Figure 1: Proportion of waste water from different sources (Source RCC)

\section{Materials and Methods}

\section{Selection of Sample Location}

Rajshahi District, which covers an area of $2407 \mathrm{~km}^{2}$, of which $62 \mathrm{~km}^{2}$ is river, is located in the north west of Bangladesh bordering India to the south '(BBS, 
1993)'. Rajshahi City Corporation (RCC), which was formed in 1987, covers an area of approximately 48 $\mathrm{km}^{2}$ being bounded on the east, north and west by Paba Thana (subdivision of a district) and on the south by the Padma River. A number of storm water drains flow from the south of Rajshahi City Corporation to the north either terminating in beels or in the Baranai River some $15 \mathrm{~km}$ away. An initial assessment of the city was conducted at the beginning of the study and four project locations were identified where waste water is being used in agriculture. These sites are situated along two of the city drains such as Circuit House drain and Dargapara drain. The Circuit House Drain starts in Ward 7 (from the place identified as Circuit House Road), flows through Ward 3, along the edge of Ward 6. It passes by the Rajshahi Metropolitan Police, Medicine Corner, Rajshahi Medical College Hospital, Clinic and Women's Complex. After that the Circuit House
Drain enters Bashuar Beel, in Ward 14 and emerges at the other end of the beel before flowing through agricultural land in Ward 14, Paba Thana and Ward 17, and into Baranai River (Figure 2) The Dargapara Drain starts from Natore Road in Ward 9. It flows through Ward 10, Ward 14, and Ward 16, passing by Rajshahi Medical College, a women's hostel, Sadar (Main) Hospital, the Passport Office, the Fisheries Office and the Cantonment Area, as well as some densely populated residential areas. In Ward 16, second drain joins the Dargapara Drain bringing untreated industrial effluent from the Bangladesh small and Cottage lndustry Corporation (BSCIC) area and meets at Sopura also known as BSCIC drain. In Ward 3, the BSCIC Drain and the CITY Drain meet finally flows on Basuar Beel and is continuously used for agricultural purposes (RCC, 2006). The sites selected are listed in Table 1 and depicted in the map (Figure 2).

Table 1: Water Quality Monitoring Site Codes and Descriptions

\begin{tabular}{|l|l|}
\hline Site Code & Sample Location Points in Rajshahi City Corporation \\
\hline A & BSCIC Drain Sopura \\
\hline B & CITY Drain \\
\hline C & Combination of BSCIC and CITY Drain \\
\hline D & Basuar Beel \\
\hline
\end{tabular}

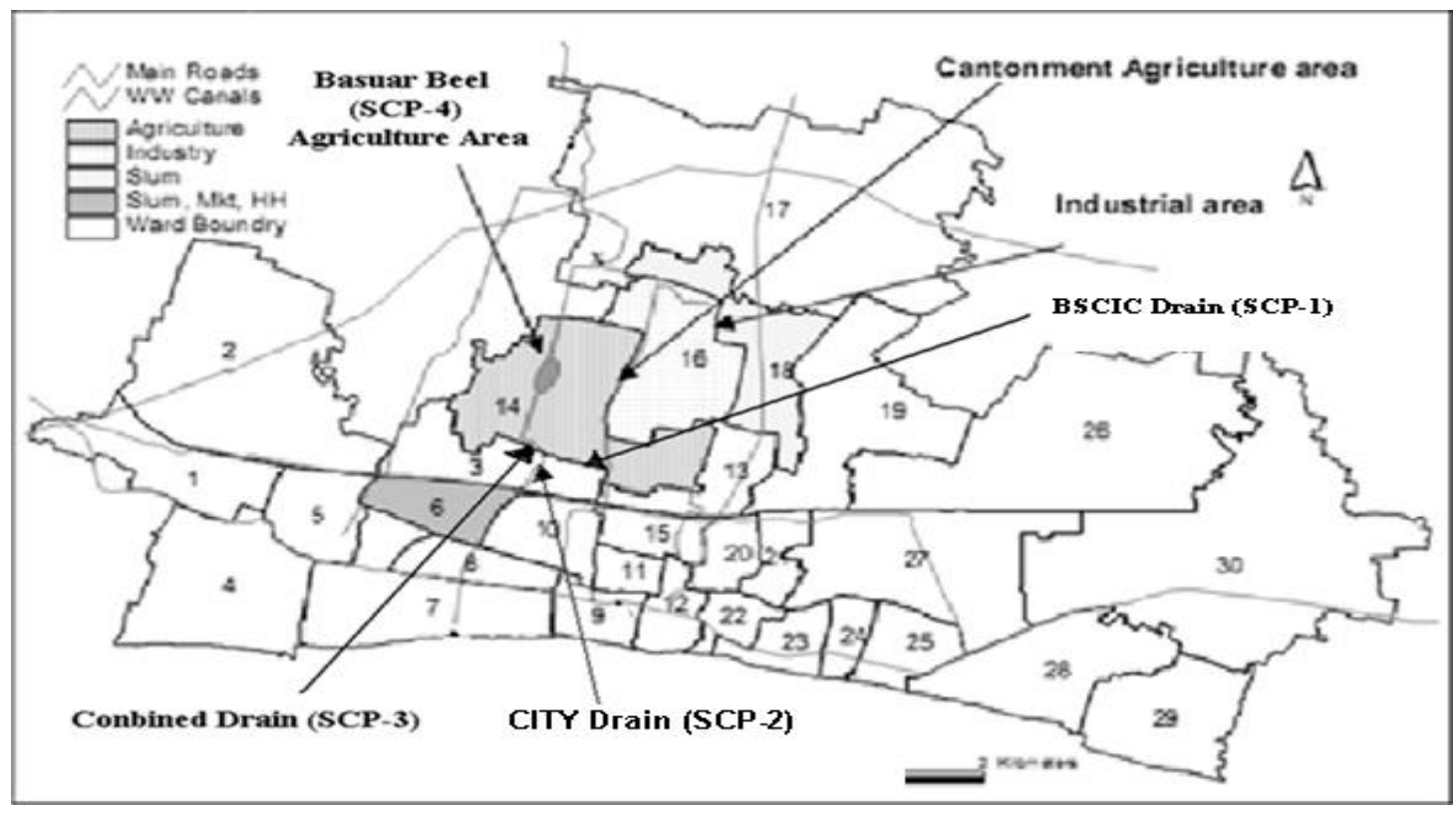

Figure 2: Sample collection points (Source RCC 2006)

\section{Sampling Methodology}

Analysis of sample was performed with strict quality control and quality assurance using the internationally accepted analytical chemical methods of analysis.
Measurements of all of the water quality parameters were conducted at Public Health Lab in RUET. The method which was carried out during testing is listed below. 
Table 2: Water Quality Parameters Measurement Method '(APHA, 2001)'

\begin{tabular}{|l|l|}
\hline Water Quality Parameters & Methodology Reference \\
\hline $\mathrm{pH}$ & Colorimetric or Electrometric method \\
\hline Total Solids, Dissolved Solids and Suspend Solids & APHA 2540 C, APHA 2540 D \\
\hline Biochemical Oxygen Demand (BOD) & APHA 5210 B \\
\hline Chemical Oxygen Demand (COD) & APHA 5220 B \\
\hline Dissolved Oxygen (DO) & APHA 4500 O G \\
\hline Sodium (Na) & EDTA titration method \\
\hline Magnesium (Mg) & EDTA titration method \\
\hline Calcium (Ca) & EDTA titration method \\
\hline Total Nitrogen (N) & Titanium Trichloride Reduction Method (Method 10021) \\
\hline Total Phosphorus (P) & PhosVer 3 with Acid Persulfate Digestion (Method 8190) \\
\hline Potassium (K) & APHA 3111 B \\
\hline Total Coli form & Membrane Filtration Method \\
\hline
\end{tabular}

\section{Results and Discussion}

The suitable $\mathrm{pH}$ range for the existence of most biological life is quite narrow and critical, and standard range for irrigation water is $\mathrm{pH}$ 6.5-8.5. The $\mathrm{pH}$ value in the project location was mildly acidic to neutral (Figure 3). The reason may be use of various chemical in industry where acidogenesis reaction takes place that slightly decreases the $\mathrm{pH}$ limit.

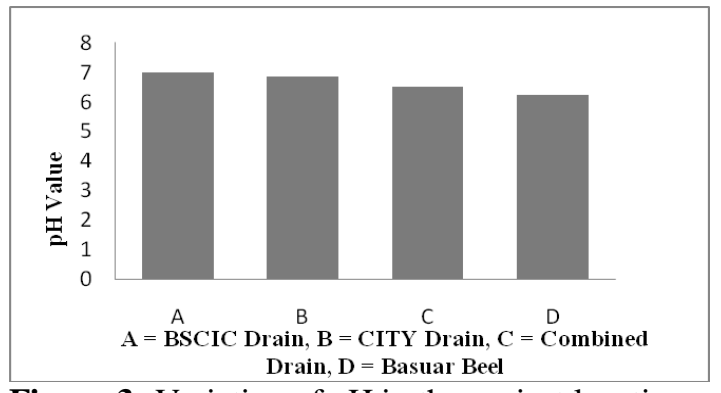

Figure 3: Variation of $\mathrm{pH}$ in the project location

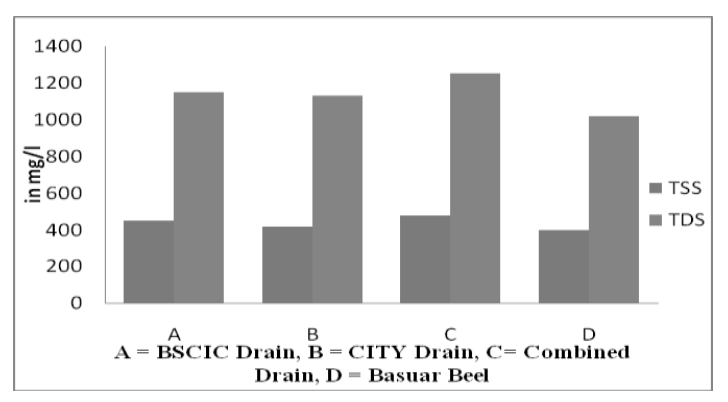

Figure 4: Variation of TSS \& TDS in the project location

The Food and Agriculture Organization (FAO) has developed guidelines for the evaluation of water quality for irrigation and suggests that, no restrictions on the use of irrigation water with an TSS and TDS concentration of less than $100 \mathrm{mg} / \mathrm{l}$ and $450 \mathrm{mg} / \mathrm{l}$ respectively; slight to moderate restrictions if concentrations are in the range of 100-200 mg / and $450-2000 \mathrm{mg} / \mathrm{l}$; and severe restrictions for irrigation water with an TSS and TDS concentration of more than $200 \mathrm{mg} / \mathrm{l}$ and $2000 \mathrm{mg} / \mathrm{l}$ respectively (Ayres and Westcot, 1985). TDS \& TSS were higher in all drain and exceeded the no restriction level (Figure 4).

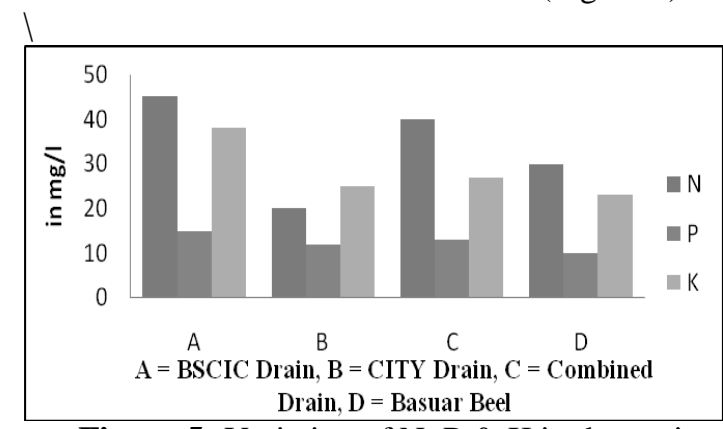

Figure 5: Variation of N, P \& K in the project location

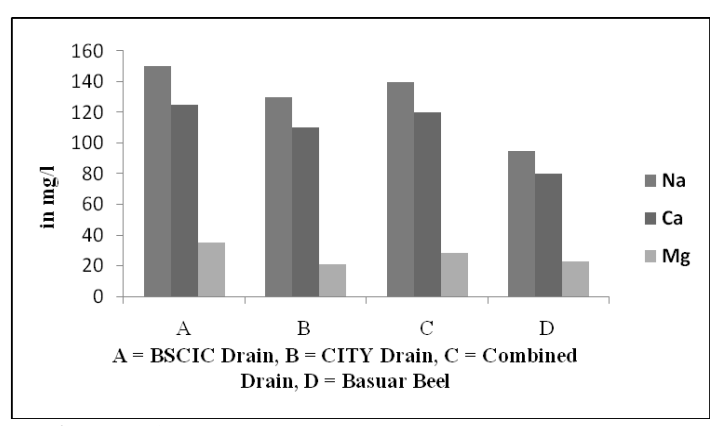

Figure 6: Variation of $\mathrm{Na}, \mathrm{Ca} \& \mathrm{Mg}$ in the project location

Nitrogen, phosphorous and potassium are necessary primary macronutrient for plants that stimulates plant growth. Wastewater with a total nitrogen and phosphorous concentration of $80 \mathrm{mg} / 1$ and $20 \mathrm{mg} / \mathrm{l}$ is considered strong, $40 \mathrm{mg} / 1$ and $10 \mathrm{mg} / \mathrm{l}$ as medium and $20 \mathrm{mg} / \mathrm{l}$ and $6 \mathrm{mg} / \mathrm{l}$ as weak respectively (Pescod, 
1992). If excess nitrogen is applied to a crop it can result in over-stimulation and excessive growth which increase susceptibility to pest and disease attacks, delayed maturity, failure to ripen, reduced crop quality and yield loss. Excess phosphorus can lead to noxious algal blooms in water bodies (Pescod, 1992). In the BSCIC Drain and Combined Drain, total $\mathrm{N}$ and total $\mathrm{P}$ concentration $\mathrm{s}$ high because of phosphorus and nitrogen entered into the drain from domestic waste; detergents and leaching from the agricultural area (Figure 5). The concentration was lower in the beel may be due to natural treatment processes taking place or dilution. Generally, irrigation water contains low potassium concentrations, insufficient to cover the plant's theoretical demand. The normal concentration of $\mathrm{K}$ in treated wastewaters is $30 \mathrm{mg} / \mathrm{l}$ and is $0-2 \mathrm{mg} / 1$ in irrigation water (Pescod, 1992; Ayres and Westcot, 1985). The reported $\mathrm{K}$ values for the project area ranged from 23 to $38 \mathrm{mg} / 1$ and the highest reported value was for the most downstream location on the BSCIC Drain.

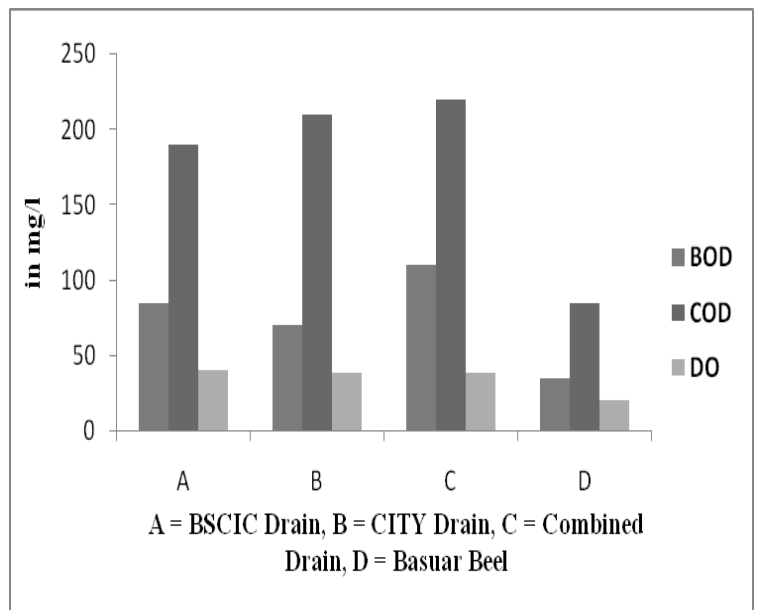

Figure 7: Variation of BOD, COD \& DO in the Project location

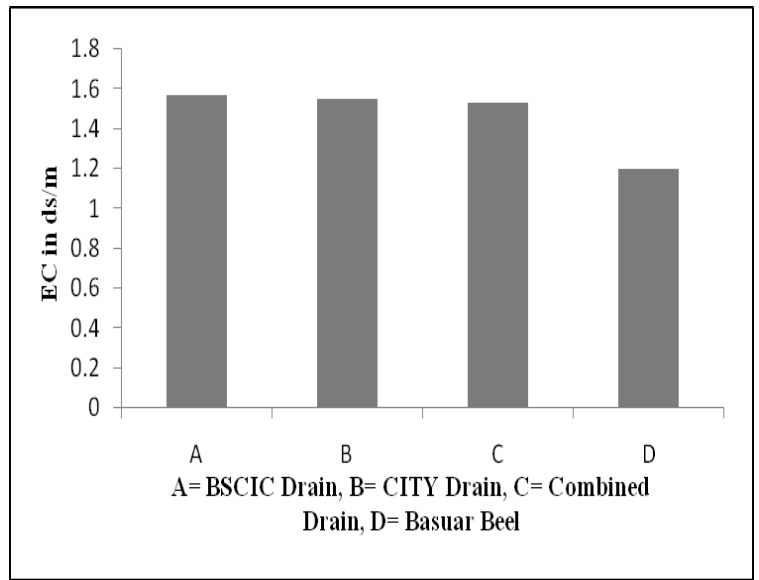

Figure 8: Variation of EC in the Project Location
The value of $\mathrm{Na}, \mathrm{Ca} \& \mathrm{Mg}$ in the project location was ranged from $95-150 \mathrm{mg} / \mathrm{l}, 80-125 \mathrm{mg} / \mathrm{l} \& 23-35 \mathrm{mg} / \mathrm{l}$, respectively (Figure 6). In industrial processs, soda lime, detergent and various salts of sodium are use that increases the $\mathrm{Na}$ in the waste water. Exchangeable form of sodium changes the physicochemical properties of the soil and has the ability to disperse soil particles that results in reduced air and water infiltration to the soil and the formation of a hard crust when the soil is dry (Pescod, 1992). The $\mathrm{EC}$ of irrigation water is important because it is a measure of the salinity of the water.

According to FAO no restrictions on the use of irrigation water with an EC of $0.7 \mathrm{dS} / \mathrm{m}$, slight to moderate restrictions if concentrations are in the ranged of $0.7-3.0 \mathrm{dS} / \mathrm{m}$ and severe restrictions for irrigation water with an EC of greater than $3.0 \mathrm{dS} / \mathrm{m}$ (Ayres and Westcot, 1985). The EC value of the study area ranged from 1.2-1.5 $\mathrm{dS} / \mathrm{m}$ indicated slight to moderate restriction for irrigation (Figure 8). The BOD, COD and DO values in the project location ranges from $35-85 \mathrm{mg} / \mathrm{l}, 85-190 \mathrm{mg} / \mathrm{l}$ and $20-40 \mathrm{mg} / \mathrm{l}$ respectively (Figure 7). According to WHO (2006) municipal wastewater with $\mathrm{BOD}, \mathrm{COD}$ and $\mathrm{DO}$ concentration in the range of $110-400 \mathrm{mg} / 1,250-1000$ $\mathrm{mg} / \mathrm{l}$ and $4.5-8.5 \mathrm{mg} / \mathrm{l}$ can increase crop productivity. The value of DO is lower in the project location. The reason for that presence of organic matter is higher in three locations and for decomposition of this organic matter more oxygen is required.

The WHO guidelines for wastewater used in agriculture suggested maximum Faecal Coliform of less than 1000 thermo tolerant coli/ $100 \mathrm{ml}$ for root crops likely to be eaten uncooked, and 10,000 thermo tolerant coli/100 ml for leaf crops likely to be eaten uncooked but no standard for irrigation of cereal crops (WHO, 2006). Faecal Coliform in all tested drain water samples did not comply with the WHO guidelines for use of wastewater in agriculture (WHO, 2006).

\section{Conclusion}

On the basis of test results in this study, it is concluded that the biological quality parameters in wastewater which is used in agricultural purposes are not satisfied with the FAO and WHO guidelines. The most concerning factor is that, the wastewater in the study area having high level of faecal contamination. The TDS, TSS, Na, N, P, BOD, EC and SAR value in the study area is also high. Hence, waste stabilization pond with addition of gypsum and macrophytes pond can be effectively used to reduce the harmful effect of these parameters for proper irrigation. In this way, significant water saving can be achieved and farmer incomes can be raised. 


\section{References}

American Public Health Association, American Water Works Association, Water Environment Federation, 2001. Standard Methods for the Examination of Water and Wastewater, $20^{\text {th }}$ Edition. Washington, D.C.: APHA/AWWA/WEF.

Ahmed, M. F. and Rahman, M. M. 2000 Water supply and Sanitation, Rural and Low Income Urban Communities. Bangladesh, ITN. pp. 228-234

Ayres, R. S. and Westcot, D. W.1985. Water Quality for Agriculture. FAO Irrigation and Drainage Paper 29 Rev 1. Rome, Italy: FAO.

Bangladesh Bureau of Statistics (BBS). 1993. Bangladesh Population Census 1991, Zila: Rajshahi. Dhaka, Bangladesh, Government of the People's Republic of Bangladesh.

Jayakody, P; Amin, M. M. and Clemett, A. 2007.Wastewater Agriculture in Rajshahi
City, Bangladesh. WASPA Asia Project Report 9. IWMI: Colombo, Sri Lanka.

Pescod, M. B. 1992. Wastewater Treatment and Use in Agriculture. Rome, Italy: FAO.

Rajshahi Development Authority (RDA), 2004. Rajshahi Metropolitan Development Plan. 2004-2024.Volume-II Detailed Area Plan. Prepared by RDA under the Ministry of Housing and Public Works Government of the People's Republic of Bangladesh.

Rajshahi City Corporation (RCC), 2006. RCC Development Plan, 2004-2012, Volume1. Prepared by RCC under the Ministry of Local Government \& Rural Development of the People's Republic of Bangladesh Nagor bhaban, Rajshahi.

World Health Organization, 2006. WHO Guidelines for the Safe Use of Wastewater, Excreta and Grey water: Volume II Wastewater use in Agriculture. Geneva, Switzerland: WHO. 